CRYSTALLOGRAPHIC COMMUNICATIONS

ISSN 2056-9890

\section{Crystal structure, Hirshfeld surface analysis and interaction energy and DFT studies of 4-[(prop-2- en-1-yloxy)methyl]-3,6-bis(pyridin-2-yl)pyridazine}

\author{
Mouad Filali, ${ }^{a}$ Nada Kheira Sebbar, ${ }^{b, c *}{ }^{\text {Tuncer Hökelek, }}{ }^{\text {d Joel T. Mague, }}{ }^{\text {e Said }}$ \\ Chakroune, ${ }^{a}$ Abdessalam Ben-Tama ${ }^{a}$ and El Mestafa El Hadramia
}

Received 29 July 2019

Accepted 10 August 2019

Edited by A. J. Lough, University of Toronto, Canada

Keywords: crystal structure; pyridine; pyridazine; $\pi$-stacking; DFT; Hirshfeld surface.

CCDC reference: 1946685

Supporting information: this article has supporting information at journals.iucr.org/e

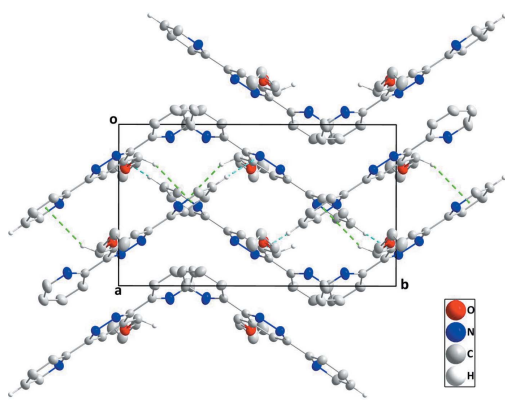

OPEN $\odot$ ACCESS
aLaboratoire de Chimie Organique Appliquée, Université Sidi Mohamed Ben Abdallah, Faculté des Sciences et Techniques, Route d'Immouzzer, BP 2202, Fez, Morocco, 'baboratoire de Chimie Bioorganique Appliquée, Faculté des Sciences, Université Ibn Zohr, Agadir, Morocco, 'Laboratoire de Chimie Organique Hétérocyclique URAC 21, Pôle de Compétence Pharmacochimie, Av. Ibn Battouta, BP 1014, Faculté des Sciences, Université Mohammed V, Rabat, Morocco, ${ }^{\mathbf{d}}$ Department of Physics, Hacettepe University, 06800 Beytepe, Ankara, Turkey, and ${ }^{\mathbf{e}}$ Department of Chemistry, Tulane University, New Orleans, LA 70118, USA. *Correspondence e-mail: nadouchsebbarkheira@gmail.com

The title compound, $\mathrm{C}_{18} \mathrm{H}_{16} \mathrm{~N}_{4} \mathrm{O}$, consists of a 3,6-bis(pyridin-2-yl)pyridazine moiety linked to a 4-[(prop-2-en-1-yloxy)methyl] group. The pyridine-2-yl rings are oriented at a dihedral angle of $17.34(4)^{\circ}$ and are rotated slightly out of the plane of the pyridazine ring. In the crystal, $\mathrm{C}-\mathrm{H}_{\mathrm{Pyrd}} \cdots \mathrm{N}_{\mathrm{Pyrdz}}(\mathrm{Pyrd}=$ pyridine and Pyrdz $=$ pyridazine $)$ hydrogen bonds and $\mathrm{C}-\mathrm{H}_{\text {Prpoxy }} \cdots \pi($ Prpoxy $=$ prop $-2-$ en-1-yloxy) interactions link the molecules, forming deeply corrugated layers approximately parallel to the $b c$ plane and stacked along the $a$-axis direction. Hirshfeld surface analysis indicates that the most important contributions for the crystal packing are from $\mathrm{H} \cdots \mathrm{H}(48.5 \%), \mathrm{H} \cdots \mathrm{C} / \mathrm{C} \cdots \mathrm{H}(26.0 \%)$ and $\mathrm{H} \cdots \mathrm{N} /$ $\mathrm{N} \cdots \mathrm{H}(17.1 \%)$ contacts, hydrogen bonding and van der Waals interactions being the dominant interactions in the crystal packing. Computational chemistry indicates that in the crystal, the $\mathrm{C}-\mathrm{H}_{\mathrm{Pyrd}} \cdots \mathrm{N}_{\mathrm{Pyrdz}}$ hydrogen-bond energy is $64.3 \mathrm{~kJ} \mathrm{~mol}^{-1}$. Density functional theory (DFT) optimized structures at the B3LYP/6-311 G(d,p) level are compared with the experimentally determined molecular structure in the solid state. The HOMO-LUMO behaviour was elucidated to determine the energy gap.

\section{Chemical context}

3,6-Di(pyridin-2-yl)pyridazine and its derivatives are aromatic heterocyclic organic compounds. The syntheses of 3,6-di(pyridin-2-yl)pyridazine and its derivatives based on polyheterocycles have attracted considerable attention from pharmacists in the last few decades as they function as important pharmacophores in medicinal chemistry and pharmacology (Filali et al., 2019). 5-[3,6-Di(pyridin-2-yl)pyridazine-4-yl]-2'-deoxyuridine-5'-O-triphosphate can be used as a potential substrate for fluorescence detection and imaging of DNA (Kore et al., 2015). The systems containing this moiety have also shown remarkable corrosion inhibitory (Khadiri et al., 2016). Heterocyclic molecules such as 3,6-bis(2'-pyridyl)-1,2,4,5tetrazine have been used in transition-metal chemistry (Kaim \& Kohlmann, 1987). It is a bidentate chelate ligand popular in coordination chemistry and complexes of a wide range of metals, including iridium and palladium (Tsukada et al., 2001). As a continuation of our research work devoted to the development of 3,6-di(pyridin-2-yl)pyridazine derivatives (Filali et al., 2019), we report herein the synthesis and the molecular and crystal structures along with the Hirshfeld 
surface analysis and the intermolecular interaction energies and density functional theory (DFT) calculations for 4-[(prop2-en-1-yloxy)methyl]-3,6-bis(pyridin-2-yl)pyridazine.

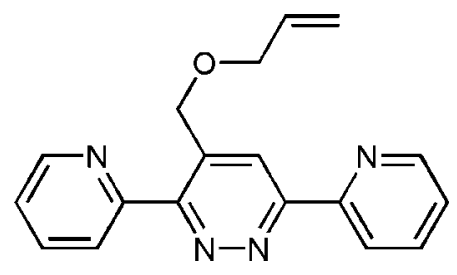

\section{Structural commentary}

The title molecule contains two pyridine and one pyradizine rings (Fig. 1). The pyradizine ring of the 3,6-bis(pyridin-2yl)pyridazine unit is linked to the 4-[(prop-2-en-1-yloxy)methyl] moiety (Fig. 1). Pyridazine ring $A$ (N1/N2/C1-C4) is oriented at dihedral angles of $2.64(3)$ and $15.06(4)^{\circ}$, respectively, to the pyridine rings $B(\mathrm{~N} 3 / \mathrm{C} 5-\mathrm{C} 9)$ and $C(\mathrm{~N} 4 /$ $\mathrm{C} 10-\mathrm{C} 14)$, while the dihedral angle between the two pyridine rings is $17.34(4)^{\circ}$. Atom C15 is at a distance of 0.0405 (12) $\AA$ from the best plane of pyridazine ring. The 4-[(prop-2-en-1yloxy)methyl] moiety is nearly co-planar with the pyradizine ring, as indicated by the $\mathrm{O} 1-\mathrm{C} 15-\mathrm{C} 2-\mathrm{C} 3$ torsion angle of $-2.59(14)^{\circ}$.

\section{Supramolecular features}

In the crystal, $\mathrm{C}-\mathrm{H}_{\text {Pyrd }} \cdots \mathrm{N}_{\text {Pyrdz }}$ (Pyrd = pyridine, Pyrdz $=$ pyridazine) hydrogen bonds and $\mathrm{C}-\mathrm{H}_{\text {Prpoxy }} \cdots \mathrm{Cg}^{\mathrm{i}}$ [symmetry code: (i) $1-x, 1-y, 1-z ; C g$ is the centroid of pyridine $\operatorname{ring} B$

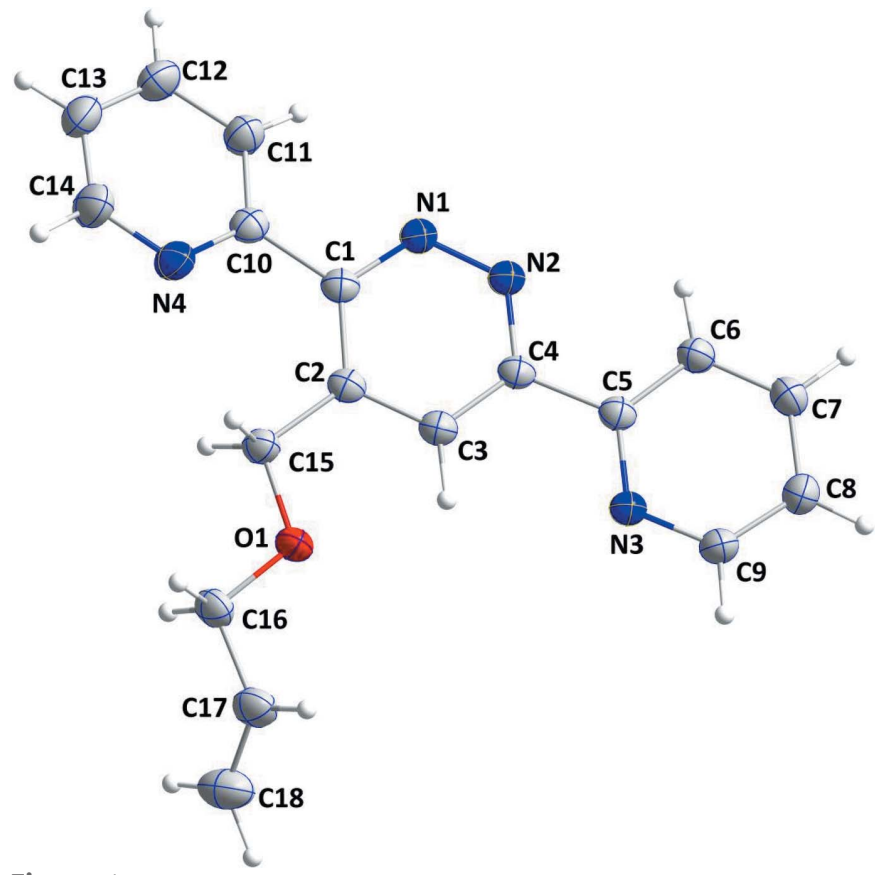

Figure 1

The molecular structure of the title compound with the atom-numbering scheme. Displacement ellipsoids are drawn at the $50 \%$ probability level.
Table 1

Hydrogen-bond geometry $\left(\AA,^{\circ}\right)$.

$C g$ is the centroid of pyridine $\operatorname{ring} B(\mathrm{~N} 3 / \mathrm{C} 5-\mathrm{C} 9)$.

\begin{tabular}{lllll}
\hline$D-\mathrm{H} \cdots A$ & $D-\mathrm{H}$ & $\mathrm{H} \cdots A$ & $D \cdots A$ & $D-\mathrm{H} \cdots A$ \\
\hline $\mathrm{C} 8-\mathrm{H} 8 \cdots \mathrm{N} 1^{\mathrm{vi}}$ & $0.966(16)$ & $2.585(16)$ & $3.4104(15)$ & $143.4(12)$ \\
$\mathrm{C} 15-\mathrm{H} 15 B \cdots C g^{\mathrm{v}}$ & $0.994(15)$ & $2.990(15)$ & $3.8760(13)$ & $149.0(11)$ \\
\hline
\end{tabular}

Symmetry codes: (v) $-x+1,-y+1,-z+1 ;$ (vi) $-x+1, y+\frac{1}{2},-z+\frac{3}{2}$.

(N3/C5-C9); Prpoxy = prop-2-en-1-yloxy] (Table 1) interactions link the molecules, forming deeply corrugated layers approximately parallel to the $b c$ plane and stacked along the $a$-axis direction (Figs. 2 and 3 ).

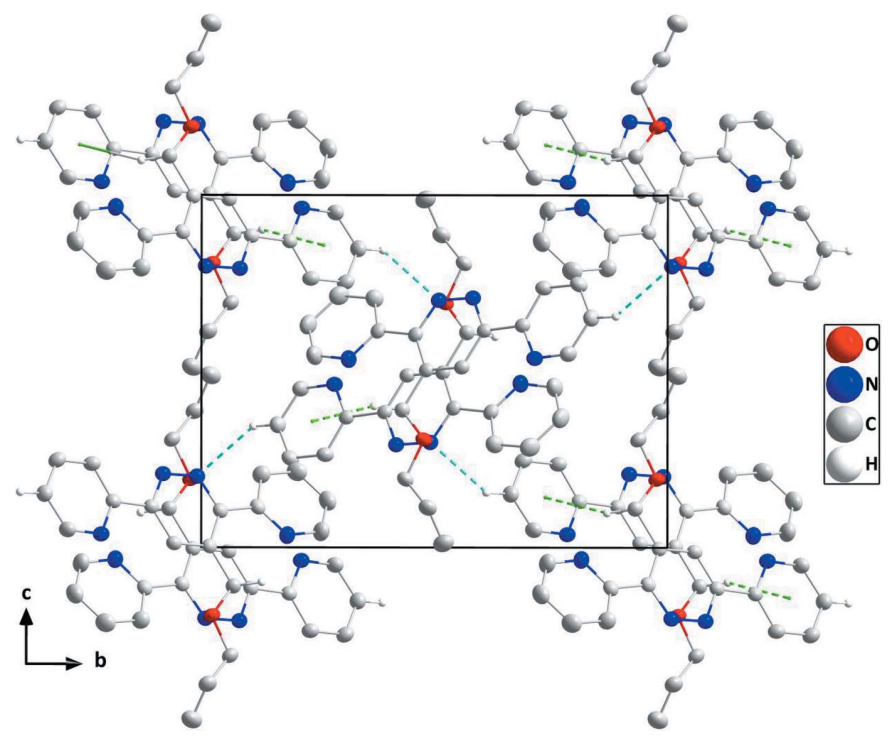

Figure 2

A partial packing diagram viewed along the $a$-axis direction with $\mathrm{C}-$ $\mathrm{H}_{\text {Pyrd }} \cdots \mathrm{N}_{\text {Pyrdz }}$ hydrogen bonds and $\mathrm{C}-\mathrm{H}_{\text {Prpoxy }} \cdots \pi$ interactions shown, respectively, as light blue and green dashed lines.

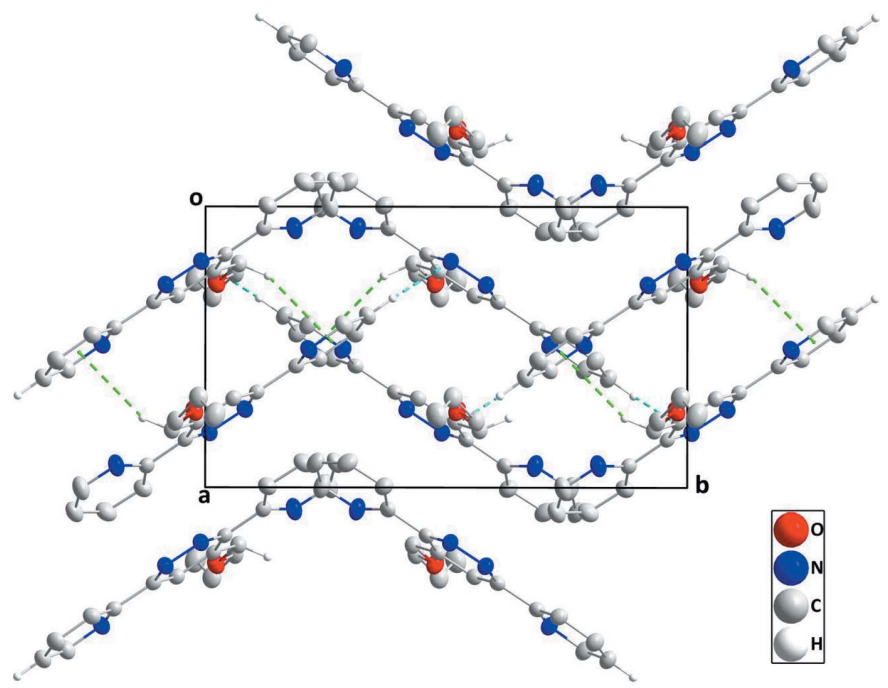

Figure 3

A partial packing diagram viewed along the $c$-axis direction with $\mathrm{C}-$ $\mathrm{H}_{\text {Pyrd }} \cdots \mathrm{N}_{\text {Pyrdz }}$ hydrogen bonds and $\mathrm{C}-\mathrm{H}_{\text {Prpoxy }} \cdots \pi$ interactions shown, respectively, as light-blue and green dashed lines. 


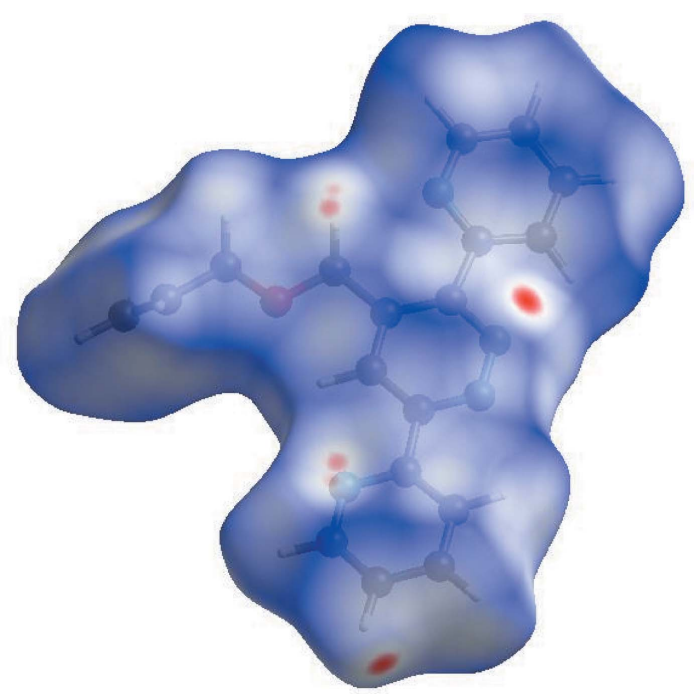

Figure 4

View of the three-dimensional Hirshfeld surface of the title compound plotted over $d_{\text {norm }}$ in the range -0.1063 to 1.1444 a.u.

\section{Hirshfeld surface analysis}

In order to visualize the intermolecular interactions, a Hirshfeld surface (HS) analysis (Hirshfeld, 1977; Spackman \& Jayatilaka, 2009) was carried out by using CrystalExplorer17.5 (Turner et al., 2017). In the HS plotted over $d_{\text {norm }}$ (Fig. 4), white areas indicate contacts with distances equal to the sum of van der Waals radii, and red and blue areas indicate distances shorter (in close contact) or longer (distinct contact) than the van der Waals radii (Venkatesan et al., 2016). The

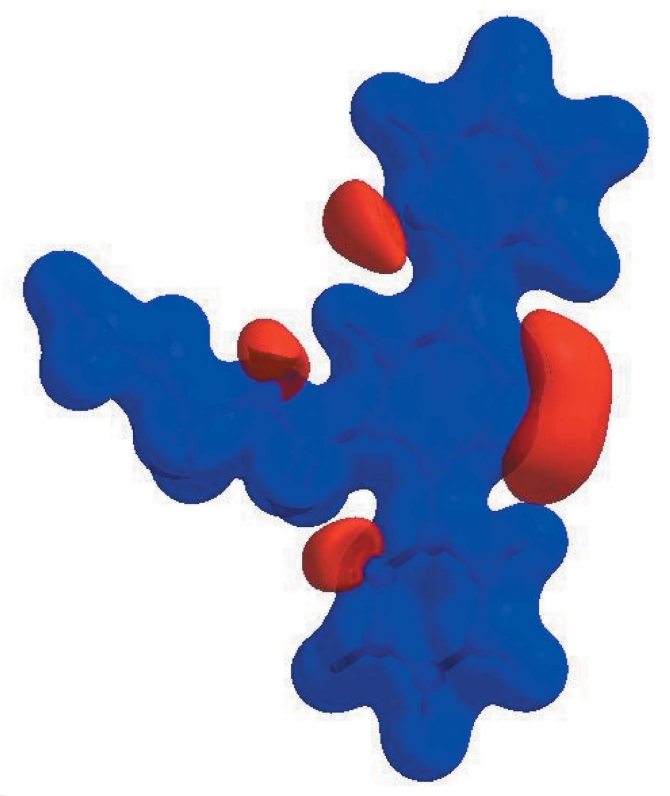

Figure 5

View of the three-dimensional Hirshfeld surface of the title compound plotted over electrostatic potential energy in the range -0.0500 to 0.0500 a.u. using the STO-3 G basis set at the Hartree-Fock level of theory. Hydrogen-bond donors and acceptors are shown as blue and red regions, respectively, around the atoms, corresponding to positive and negative potentials.
Table 2

Selected interatomic distances $(\AA)$.

\begin{tabular}{llll}
\hline $\mathrm{O} 1 \cdots \mathrm{C} 11^{\mathrm{i}}$ & $3.2992(16)$ & $\mathrm{C} 3 \cdots \mathrm{C} 11^{\mathrm{i}}$ & $3.5866(17)$ \\
$\mathrm{O} 1 \cdots \mathrm{H} 3$ & $2.232(14)$ & $\mathrm{C} 6 \cdots \mathrm{C} 12^{\mathrm{iv}}$ & $3.5808(18)$ \\
$\mathrm{O} 1 \cdots \mathrm{H} 11^{\mathrm{i}}$ & $2.850(16)$ & $\mathrm{C} 8 \cdots \mathrm{C} 10^{\mathrm{vi}}$ & $3.5797(17)$ \\
$\mathrm{N} 1 \cdots \mathrm{C} 8^{\mathrm{ii}}$ & $3.4105(15)$ & $\mathrm{C} 11 \cdots \mathrm{C} 15^{\mathrm{i}}$ & $3.5633(18)$ \\
$\mathrm{N} 4 \cdots \mathrm{C} 15$ & $2.7895(16)$ & $\mathrm{C} 1 \cdots \mathrm{H} 7^{\mathrm{ii}}$ & $2.925(17)$ \\
$\mathrm{N} 1 \cdots \mathrm{H} 8^{\mathrm{ii}}$ & $2.586(15)$ & $\mathrm{C} 6 \cdots \mathrm{H} 16 B^{\mathrm{v}}$ & $2.933(15)$ \\
$\mathrm{N} 1 \cdots \mathrm{H} 11$ & $2.441(16)$ & $\mathrm{C} 9 \cdots \mathrm{H} 15 B^{\mathrm{v}}$ & $2.842(15)$ \\
$\mathrm{N} 1 \cdots \mathrm{H} 15 A^{\mathrm{i}}$ & $2.713(14)$ & $\mathrm{C} 18 \cdots \mathrm{H} 8^{\mathrm{vii}}$ & $2.920(16)$ \\
$\mathrm{N} 2 \cdots \mathrm{H} 18 B^{\mathrm{iii}}$ & $2.86(2)$ & $\mathrm{H} 6 \cdots \mathrm{H} 9^{\mathrm{vii}}$ & $2.56(2)$ \\
$\mathrm{N} 2 \cdots \mathrm{H} 13^{\mathrm{iv}}$ & $2.744(17)$ & $\mathrm{H} 8 \cdots \mathrm{N} 1^{\mathrm{vi}}$ & $2.586(16)$ \\
$\mathrm{N} 2 \cdots \mathrm{H} 6$ & $2.455(15)$ & $\mathrm{H} 11 \cdots \mathrm{H} 16 A^{\mathrm{i}}$ & $2.57(2)$ \\
$\mathrm{N} 3 \cdots \mathrm{H} 3$ & $2.522(14)$ & $\mathrm{H} 12 \cdots \mathrm{C} 6^{\mathrm{ix}}$ & $2.886(18)$ \\
$\mathrm{N} 3 \cdots \mathrm{H} 15 B^{\mathrm{v}}$ & $2.652(15)$ & $\mathrm{H} 12 \cdots \mathrm{H} 14^{\mathrm{x}}$ & $2.53(3)$ \\
$\mathrm{N} 4 \cdots \mathrm{H} 15 A$ & $2.632(14)$ & $\mathrm{H} 13 \cdots \mathrm{H} 18 B^{\mathrm{xi}}$ & $2.55(3)$ \\
$\mathrm{N} 4 \cdots \mathrm{H} 15 B$ & $2.485(14)$ & $\mathrm{H} 15 A \cdots \mathrm{H} 16 A$ & $2.36(2)$ \\
$\mathrm{C} 1 \cdots \mathrm{C} 7^{\mathrm{ii}}$ & $3.5853(17)$ & $\mathrm{H} 15 B \cdots \mathrm{H} 16 B$ & $2.38(2)$ \\
$\mathrm{C} 2 \cdots \mathrm{C} 10^{\mathrm{i}}$ & $3.5420(15)$ & $\mathrm{H} 16 A \cdots \mathrm{H} 18 A$ & $2.33(2)$ \\
\hline
\end{tabular}

Symmetry codes: (i) $-x,-y+1,-z+1$; (ii) $-x+1, y-\frac{1}{2},-z+\frac{3}{2}$; (iii) $x, y, z+1$; (iv) $-x, y+\frac{1}{2},-z+\frac{3}{2} ; \quad$ (v) $-x+1,-y+1,-z+1 ; \quad$ (vi) $-x+1, y+\frac{1}{2},-z+\frac{3}{2} ; \quad$ (vii) $-x+1, y-\frac{1}{2},-z+\frac{1}{2}$; (viii) $x,-y+\frac{3}{2}, z+\frac{1}{2}$; (ix) $-x, y-\frac{1}{2},-z+\frac{3}{2}$; (x) $x,-y+\frac{1}{2}, z+\frac{1}{2}$; (xi) $-x, y-\frac{1}{2},-z+\frac{1}{2}$.

bright-red spots appearing near $\mathrm{N} 1$ and hydrogen atoms $\mathrm{H} 8$ and $\mathrm{H} 15 B$ indicate their roles as donors and/or acceptors; they also appear as blue and red regions corresponding to positive and negative potentials on the HS mapped over electrostatic potential (Spackman et al., 2008; Jayatilaka et al., 2005) shown in Fig. 5. The blue regions indicate positive electrostatic potential (hydrogen-bond donors), while the red regions indicate negative electrostatic potential (hydrogen-bond acceptors). The shape-index of the HS is a tool to visualize $\pi$ $\pi$ stacking by the presence of adjacent red and blue triangles; if there are no adjacent red and/or blue triangles, then there are no $\pi-\pi$ interactions. Fig. 6 clearly suggest that there are no $\pi-\pi$ interactions in (I).

The overall two-dimensional fingerprint plot, Fig. 7a, and those delineated into $\mathrm{H} \cdots \mathrm{H}, \mathrm{H} \cdots \mathrm{C} / \mathrm{C} \cdots \mathrm{H}, \mathrm{H} \cdots \mathrm{N} / \mathrm{N} \cdots \mathrm{H}$, $\mathrm{C} \cdots \mathrm{C}, \mathrm{H} \cdots \mathrm{O} / \mathrm{O} \cdots \mathrm{H}, \quad \mathrm{O} \cdots \mathrm{C} / \mathrm{C} \cdots \mathrm{O}$ and $\mathrm{C} \cdots \mathrm{N} / \mathrm{N} \cdots \mathrm{C}$ contacts (McKinnon et al., 2007) are illustrated in Fig. $7 b-h$,

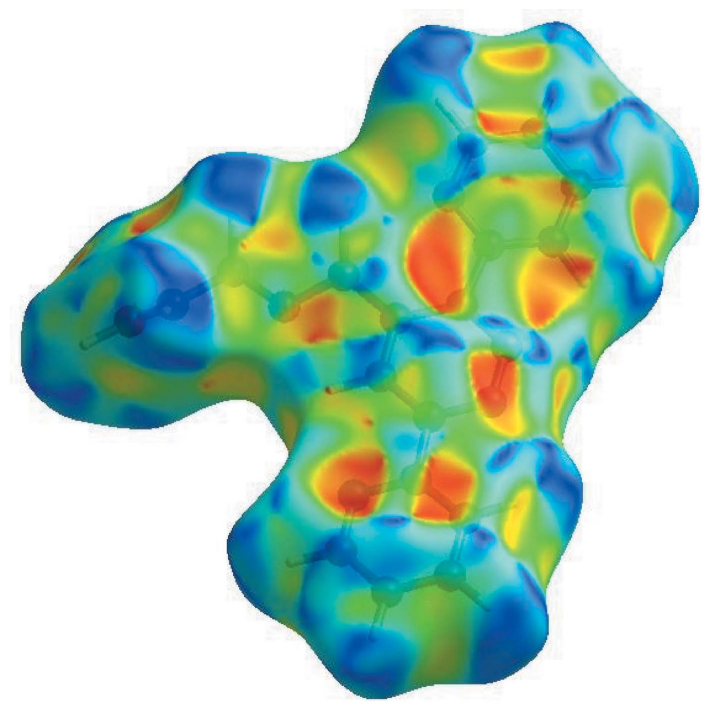

Figure 6

Hirshfeld surface of the title compound plotted over shape-index. 


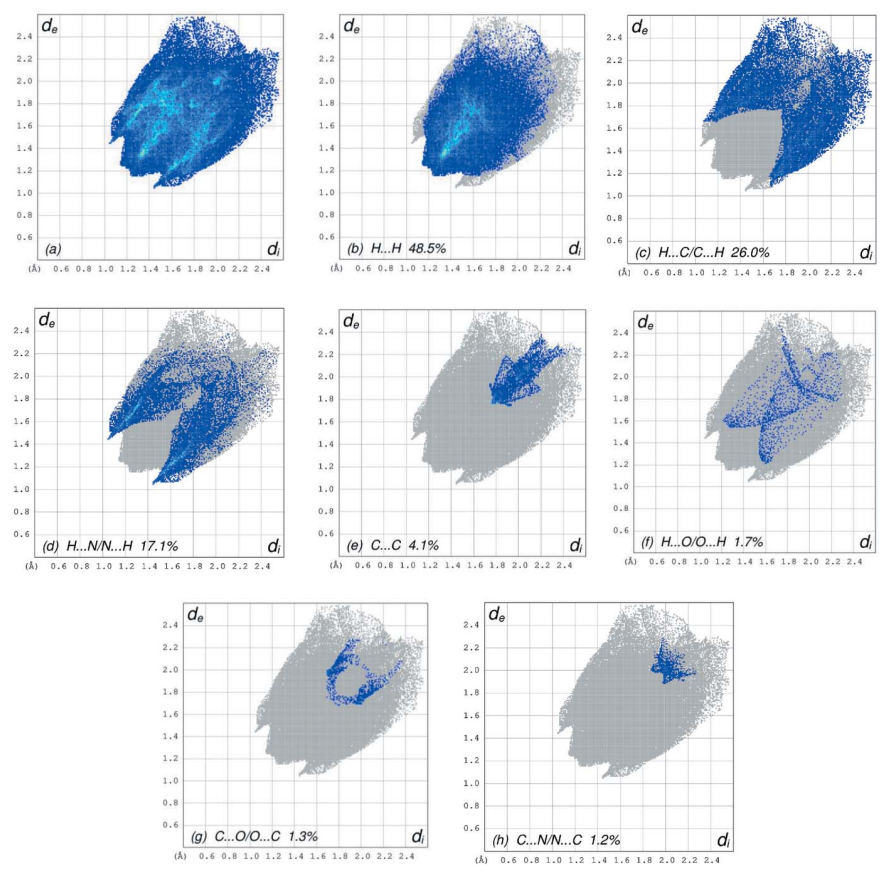

Figure 7

The full two-dimensional fingerprint plots for the title compound, showing $(a)$ all interactions, and delineated into $(b) \mathrm{H} \cdots \mathrm{H},(c) \mathrm{H} \cdots \mathrm{C} /$ $\mathrm{C} \cdots \mathrm{H},(d) \mathrm{H} \cdots \mathrm{N} / \mathrm{N} \cdots \mathrm{H},(e) \mathrm{C} \cdots \mathrm{C},(f) \mathrm{H} \cdots \mathrm{O} / \mathrm{O} \cdots \mathrm{H},(g) \mathrm{C} \cdots \mathrm{O} / \mathrm{O} \cdots \mathrm{C}$ and $(h) \mathrm{C} \cdots \mathrm{N} / \mathrm{N} \cdots \mathrm{C}$ interactions. The $d_{\mathrm{i}}$ and $d_{\mathrm{e}}$ values are the closest internal and external distances (in $\AA$ ) from given points on the Hirshfeld surface.

respectively, together with their relative contributions to the Hirshfeld surface. The most important interaction is $\mathrm{H} \cdots \mathrm{H}$ (Table 2), contributing $48.5 \%$ to the overall crystal packing, which is reflected in Fig. $7 b$ as widely scattered points of high density, due to the large hydrogen content of the molecule, with the tips at $d_{\mathrm{e}}+d_{\mathrm{i}} \sim 2.39 \AA$. In the presence of $\mathrm{C}-\mathrm{H} \cdots \pi$ interactions, the pair of characteristic wings in the fingerprint plot delineated into $\mathrm{H} \cdots \mathrm{C} / \mathrm{C} \cdots \mathrm{H}$ contacts $(26.0 \%$ contribution), Fig. $7 c$, has a pair of spikes with the tips at $d_{e}+d_{i}=$ $2.72 \AA$. The pair of the scattered points of wings in the fingerprint plots delineated into $\mathrm{H} \cdots \mathrm{N} / \mathrm{N} \cdots \mathrm{H} \quad(17.1 \%$ contribution), Fig. $7 d$, has a symmetrical distribution of points with the edges at $d_{\mathrm{e}}+d_{\mathrm{i}}=2.50 \AA$. The $\mathrm{C} \cdots \mathrm{C}$ contacts, Fig. $7 e$, have an arrow-shaped distribution of points with the tip at $d_{\mathrm{e}}=$ $d_{\mathrm{i}}=1.76 \AA$. The pair of characteristic wings in the fingerprint plot delineated into $\mathrm{H} \cdots \mathrm{O} / \mathrm{O} \cdots \mathrm{H}$ contacts $(1.7 \%$ contribution) Fig. $7 f$, has a pair of spikes with the tips at $d_{\mathrm{e}}+d_{\mathrm{i}}=$ $2.82 \AA$. Finally, in the fingerprint plots delineated into $\mathrm{C} \cdots \mathrm{O}$ / O $\cdots \mathrm{C}(1.3 \%)$ and $\mathrm{C} \cdots \mathrm{N} / \mathrm{N} \cdots \mathrm{C}(1.2 \%)$ contacts, Fig. $7 g$ and Fig. $7 h$, the tips are at $d_{\mathrm{e}}=d_{\mathrm{i}}=1.65 \AA$ and $3.87 \AA$, respectively.

The Hirshfeld surface representations with the function $d_{\text {norm }}$ plotted onto the surface are shown for the $\mathrm{H} \cdots \mathrm{H}$, $\mathrm{H} \cdots \mathrm{C} / \mathrm{C} \cdots \mathrm{H}$ and $\mathrm{H} \cdots \mathrm{N} / \mathrm{N} \cdots \mathrm{H}$ interactions in Fig. $8 a-c$, respectively.

The Hirshfeld surface analysis confirms the importance of $\mathrm{H}$-atom contacts in establishing the packing. The large number of $\mathrm{H} \cdots \mathrm{H}, \mathrm{H} \cdots \mathrm{C} / \mathrm{C} \cdots \mathrm{H}$ and $\mathrm{H} \cdots \mathrm{N} / \mathrm{N} \cdots \mathrm{H}$ interactions suggest that van der Waals interactions and hydrogen bonding play the major roles in the crystal packing (Hathwar et al., 2015).

\section{Interaction energy calculations}

The intermolecular interaction energies were calculated using the CE-B3LYP/6-31G(d,p) energy model available in CrystalExplorer17.5 (Turner et al., 2017), where a cluster of molecules would need to be generated by applying crystallographic symmetry operations with respect to a selected central molecule within the radius of $3.8 \AA$ by default (Turner et al., 2014). The total intermolecular energy $\left(E_{\text {tot }}\right)$ is the sum of electrostatic $\left(E_{\text {ele }}\right)$, polarization $\left(E_{\text {pol }}\right)$, dispersion $\left(E_{\mathrm{dis}}\right)$ and exchange-repulsion $\left(E_{\mathrm{rep}}\right)$ energies (Turner et al., 2015) with scale factors of $1.057,0.740,0.871$ and 0.618 , respectively (Mackenzie et al., 2017). The hydrogen-bonding interaction energy (in $\mathrm{kJ} \mathrm{mol}^{-1}$ ) was calculated as -15.0 $\left(E_{\text {ele }}\right),-3.2\left(E_{\text {pol }}\right),-81.9\left(E_{\text {dis }}\right), 40.9\left(E_{\text {rep }}\right)$ and $-64.3\left(E_{\text {tot }}\right)$ for the $\mathrm{C}-\mathrm{H}_{\text {Pyrd }} \cdots \mathrm{N}_{\text {Pyrdz }}$ hydrogen bond.

\section{DFT calculations}

The optimized structure of the title compound in the gas phase was generated theoretically via density functional theory (DFT) using standard B3LYP functional and 6-311 G(d,p) basis-set calculations (Becke, 1993) as implemented in GAUSSIAN 09 (Frisch et al., 2009). The theoretical and experimental results were in good agreement (Table 3 ). The highest-occupied molecular orbital (HOMO), acting as an electron donor, and the lowest-unoccupied molecular orbital (LUMO), acting as an electron acceptor, are very important parameters for quantum chemistry. When the energy gap is

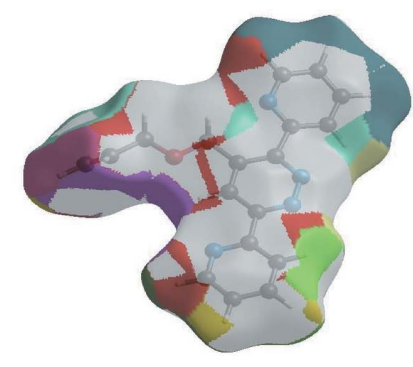

(a)

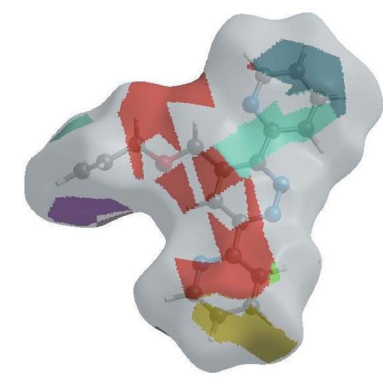

(b)

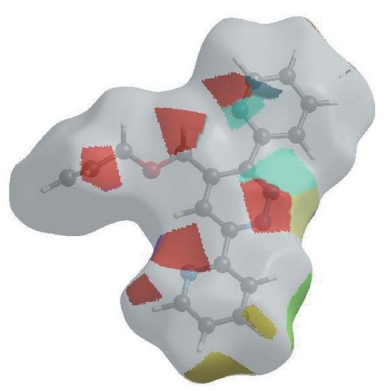

(c)

Figure 8

The Hirshfeld surface representations with the function $d_{\text {norm }}$ plotted onto the surface for $(a) \mathrm{H} \cdots \mathrm{H},(b) \mathrm{H} \cdots \mathrm{C} / \mathrm{C} \cdots \mathrm{H}$ and $(c) \mathrm{H} \cdots \mathrm{N} / \mathrm{N} \cdots \mathrm{H}$ interactions. 
Table 3

Comparison of the selected (X-ray and DFT) geometric data $\left(\AA{ }^{\circ}\right)$.

\begin{tabular}{lll}
\hline Bonds/angles & X-ray & B3LYP/6-311G(d,p) \\
\hline O1-C15 & $1.4224(13)$ & 1.45001 \\
O1-C16 & $1.4237(14)$ & 1.45647 \\
N1-N2 & $1.3322(13)$ & 1.33754 \\
N1-C1 & $1.3434(15)$ & 1.36030 \\
N2-C4 & $1.3386(14)$ & 1.35694 \\
N3-C9 & $1.3370(15)$ & 1.34713 \\
N3-C5 & $1.3445(14)$ & 1.35667 \\
N4-C10 & $1.3362(15)$ & 1.35644 \\
N4-C14 & $1.3400(17)$ & 1.34940 \\
C15-O1-C16 & $111.09(9)$ & 112.34477 \\
N2-N1-C1 & $121.37(9)$ & 121.70569 \\
N1-N2-C4 & $119.14(9)$ & 119.30129 \\
C9-N3-C5 & $117.07(10)$ & 118.58051 \\
C10-N4-C14 & $117.42(11)$ & 119.00361 \\
N1-C1-C2 & $121.82(10)$ & 121.25910 \\
N1-C1-C10 & $113.24(10)$ & 113.37034 \\
N2-C4-C3 & $122.25(10)$ & 121.78580 \\
N2-C4-C5 & $115.80(10)$ & 116.28262 \\
C3-C4-C5 & $121.95(10)$ & 121.93158 \\
N3-C5-C6 & $122.61(10)$ & 122.07926 \\
N3-C5-C4 & $116.15(10)$ & 116.59443 \\
\hline
\end{tabular}

small, the molecule is highly polarizable and has high chemical reactivity. The DFT calculations provide some important information on the reactivity and site selectivity of the molecular framework. $E_{\mathrm{HOMO}}$ and $E_{\mathrm{LUMO}}$ clarify the inevitable charge-exchange collaboration inside the studied material, and are given in Table 4 along with the electronegativity $(\chi)$, hardness $(\eta)$, potential $(\mu)$, electrophilicity $(\omega)$ and softness $(\sigma)$. The significance of $\eta$ and $\sigma$ is to evaluate both the reac-
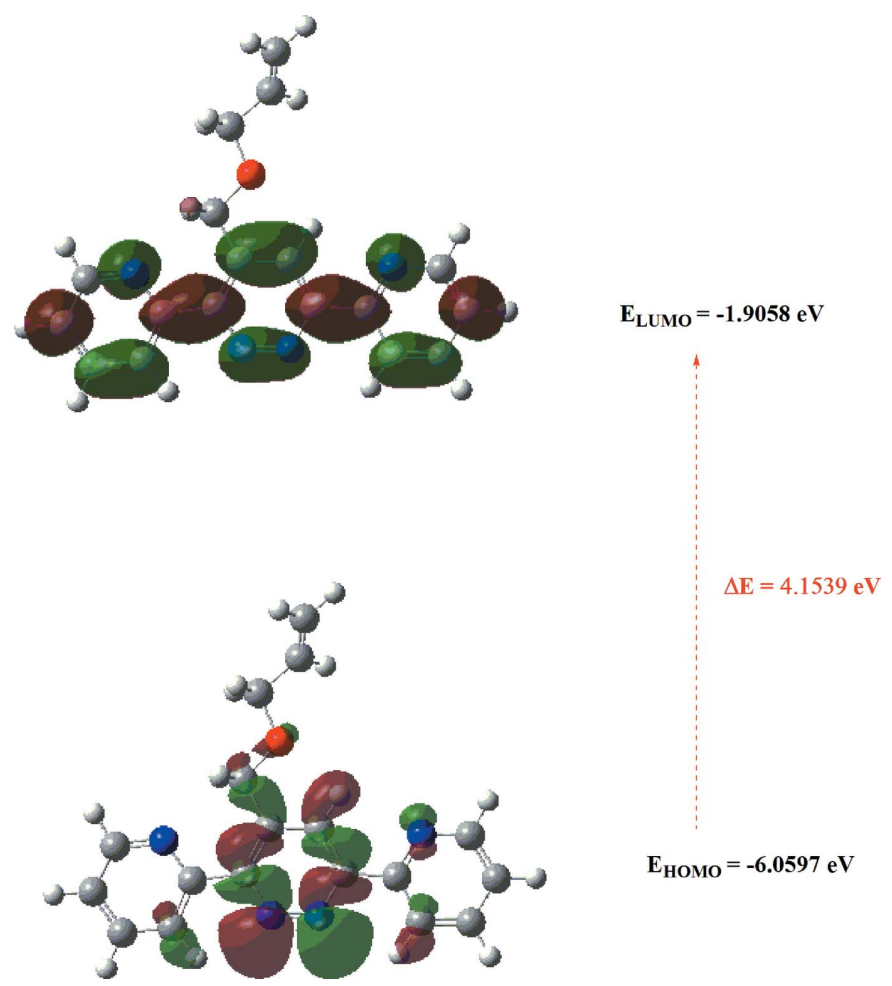

$\mathrm{E}_{\text {номо }}=-6.0597 \mathrm{eV}$

Figure 9

The energy band gap of the title compound.
Table 4

Calculated energies for the title compound.

\begin{tabular}{lr}
\hline Total energy, $T E(\mathrm{eV})$ & -26922.3681 \\
$E_{\text {HOMO }}(\mathrm{eV})$ & -6.0597 \\
$E_{\text {LUMO }}(\mathrm{eV})$ & -1.9058 \\
Energy gap, $\Delta E(\mathrm{eV})$ & 4.1539 \\
Dipole moment $\mu(\mathrm{Debye})$ & 1.6276 \\
Ionization potential, $I(\mathrm{eV})$ & 6.0597 \\
Electron affinity, $A$ & 1.9058 \\
Electronegativity, $\chi$ & 3.9827 \\
Hardness, $\eta$ & 2.0769 \\
Electrophilicity index, $\omega$ & 3.8186 \\
Softness, $\sigma$ & 0.4815 \\
Fraction of electrons transferred, $\Delta N$ & 0.7264 \\
\end{tabular}

tivity and stability. The electron transition from the HOMO to the LUMO energy level is shown in Fig. 9. The HOMO and LUMO are localized in the plane extending from the whole 4-[(prop-2-en-1-yloxy)methyl]-3,6-bis(pyridin-2-yl)pyridazine ring. The energy band gap $\left[\Delta E=E_{\mathrm{LuMO}}-E_{\mathrm{HOMO}}\right]$ of the molecule is $4.1539 \mathrm{eV}$, and the frontier molecular orbital energies, $E_{\mathrm{HOMO}}$ and $E_{\mathrm{LUMO}}$ are -6.0597 and $-1.9058 \mathrm{eV}$, respectively.

\section{Database survey}

Silver(I) complexes supported by 3,6-di(pyridin-2-yl)pyridazine ligands have been reported (Constable et al., 2008). Three other metal complexes including 3,6-di(pyridin-2yl)pyridazine have also been reported, namely aquabis[3,6bis(pyridin-2-yl)pyridazine- $\left.\kappa^{2} N^{1}, N^{6}\right]$ copper(II) bis(trifluoromethanesulfonate) (Showrilu et al., 2017), tetrakis $[\mu-3,6$ di(pyridin-2-yl)pyridazine]bis( $\mu$-hydroxo)bis( $\mu$-aqua)tetranickel(II) hexakis(nitrate) tetradecahydrate (Marino et al., 2019) and catena-[[ $\mu_{2}-3,6-\operatorname{di}($ pyridin-2-yl)pyridazine $]$ bis $\left(\mu_{2^{-}}\right.$ azido)dizaidodicopper monohydrate] (Mastropietro et al., 2013).

\section{Synthesis and crystallization}

THF (20 ml), [3,6-di(pyridin-2-yl)pyridazin-4-yl]methanol ( $3 \mathrm{mmol}$ ), 1.8 eq. of $\mathrm{NaH}$ and 0.04 eq. of 18-crown ether $\mathrm{A}$ were added to a conical flask and stirred for $10 \mathrm{~min}$ at room temperature. Then 1.2 eq of propargyl allyl chloride was added to the reaction mixture and stirred for $48 \mathrm{~h}$. The solvent was then evaporated off and the required organic compound was obtained by liquid-liquid extraction using dichloromethane. The organic phase was dried with sodium sulfate $\left(\mathrm{Na}_{2} \mathrm{SO}_{4}\right)$, and then evaporated. The product obtained was separated by chromatography on a column of silica gel. The isolated solid was recrystallized from hexane-dichloromethane (1:1) to afford colourless crystals (yield: 87\%, m.p. $376 \mathrm{~K}$ ).

\section{Refinement}

Crystal data, data collection and structure refinement details are summarized in Table 5. The hydrogen atoms were located in a difference-Fourier map and refined freely. 
Table 5

Experimental details.

\begin{tabular}{ll}
\hline Crystal data & \\
Chemical formula & $\mathrm{C}_{18} \mathrm{H}_{16} \mathrm{~N}_{4} \mathrm{O}$ \\
$M_{\mathrm{r}}$ & 304.35 \\
Crystal system, space group & Monoclinic, $P{ }_{1} / c$ \\
Temperature $(\mathrm{K})$ & 150 \\
$a, b, c(\AA)$ & $8.9420(2), 15.1130(3), 11.5829(3)$ \\
$\beta\left({ }^{\circ}\right.$ & $100.132(1)$ \\
$V\left(\AA^{3}\right)$ & $1540.91(6)$ \\
$Z$ & 4 \\
Radiation type & $\mathrm{Cu} \mathrm{K \alpha}$ \\
$\mu\left(\mathrm{mm}^{-1}\right)$ & 0.68 \\
Crystal size $(\mathrm{mm})$ & $0.26 \times 0.24 \times 0.08$ \\
& \\
Data collection & $\mathrm{Bruker} \mathrm{D} 8 \mathrm{VENTURE}$ PHOTON \\
Diffractometer & $100 \mathrm{CMOS}$ \\
& Multi-scan $(S A D A B S ;$ Krause $e t$ \\
Absorption correction & $a l ., 2015)$ \\
& $0.86,0.95$ \\
$T_{\text {min }}, T_{\text {max }}$ & $11678,3051,2688$ \\
No. of measured, independent and & \\
$\quad$ observed $[I>2 \sigma(I)]$ reflections & 0.029 \\
$R_{\text {int }}$ & 0.625 \\
(sin $\theta / \lambda)_{\text {max }}\left(\AA^{-1}\right)$ & \\
Refinement & \\
$R\left[F^{2}>2 \sigma\left(F^{2}\right)\right], w R\left(F^{2}\right), S$ & $0.037,0.101,1.04$ \\
No. of reflections & 3051 \\
No. of parameters & 273 \\
$\mathrm{H}$-atom treatment & All H-atom parameters refined \\
$\Delta \rho_{\text {max }}, \Delta \rho_{\text {min }}\left(\mathrm{e} \AA^{-3}\right)$ & $0.18,-0.15$ \\
\hline
\end{tabular}

Computer programs: APEX3 and SAINT (Bruker, 2016), SAINT (Bruker, 2016), SHELXT (Sheldrick, 2015a), SHELXL2018 (Sheldrick, 2015b), DIAMOND (Brandenburg \& Putz, 2012) and SHELXTL (Sheldrick, 2008).

\section{Funding information}

NSF-MRI grant No. 1228232 for the purchase of the diffractometer and Tulane University for support of the Tulane Crystallography Laboratory are gratefully acknowledged. TH is grateful to the Hacettepe University Scientific Research Project Unit (grant No. 013 D04 602 004).

\section{References}

Becke, A. D. (1993). J. Chem. Phys. 98, 5648-5652.

Brandenburg, K. \& Putz, H. (2012). DIAMOND, Crystal Impact GbR, Bonn, Germany.

Bruker (2016). APEX3, SAINT and SADABS . Bruker AXS, Inc., Madison, Wisconsin, USA.
Constable, E. C., Housecroft, C. E., Neuburger, M., Reymann, S. \& Schaffner, S. (2008). Aust. J. Chem. 61, 847-853.

Filali, M., Elmsellem, H., Hökelek, T., El-Ghayoury, A., Stetsiuk, O., El Hadrami, E. M. \& Ben-Tama, A. (2019). Acta Cryst. E75, 11691174.

Frisch, M. J., Trucks, G. W., Schlegel, H. B., Scuseria, G. E., Robb, M. A., Cheeseman, J. R., et al. (2009). GAUSSIAN09. Gaussian Inc., Wallingford, CT, USA.

Hathwar, V. R., Sist, M., Jørgensen, M. R. V., Mamakhel, A. H., Wang, X., Hoffmann, C. M., Sugimoto, K., Overgaard, J. \& Iversen, B. B. (2015). IUCrJ, 2, 563-574.

Hirshfeld, H. L. (1977). Theor. Chim. Acta, 44, 129-138.

Jayatilaka, D., Grimwood, D. J., Lee, A., Lemay, A., Russel, A. J., Taylor, C., Wolff, S. K., Cassam-Chenai, P. \& Whitton, A. (2005). TONTO - A System for Computational Chemistry. Available at: http://hirshfeldsurface.net/

Kaim, W. \& Kohlmann, S. (1987). Inorg. Chem. 26, 68-77.

Khadiri, A., Saddik, R., Bekkouche, K., Aouniti, A., Hammouti, B., Benchat, N., Bouachrine, M. \& Solmaz, R. (2016). J. Taiwan Inst. Chem. Eng. 58, 552-564.

Kore, A. R., Yang, B. \& Srinivasan, B. (2015). Tetrahedron Lett. 56, 808-811.

Krause, L., Herbst-Irmer, R., Sheldrick, G. M. \& Stalke, D. (2015). J. Appl. Cryst. 48, 3-10.

Mackenzie, C. F., Spackman, P. R., Jayatilaka, D. \& Spackman, M. A. (2017). IUCrJ, 4, 575-587.

Marino, N., Bruno, R., Bentama, A., Pascual-Álvarez, A., Lloret, F., Julve, M. \& De Munno, G. (2019). CrystEngComm, 21, 917-924.

Mastropietro, T. F., Marino, N., Armentano, D., De Munno, G., Yuste, C., Lloret, F. \& Julve, M. (2013). Cryst. Growth Des. 13, 270-281.

McKinnon, J. J., Jayatilaka, D. \& Spackman, M. A. (2007). Chem. Commun. pp. 3814-3816.

Sheldrick, G. M. (2008). Acta Cryst. A64, 112-122.

Sheldrick, G. M. (2015a). Acta Cryst. A71, 3-8.

Sheldrick, G. M. (2015b). Acta Cryst. C71, 3-8.

Showrilu, K., Rajarajan, K., Martin Britto Dhas, S. A. \& Athimoolam, S. (2017). IUCrData, 2, x171142.

Spackman, M. A. \& Jayatilaka, D. (2009). CrystEngComm, 11, 19-32.

Spackman, M. A., McKinnon, J. J. \& Jayatilaka, D. (2008). CrystEngComm, 10, 377-388.

Tsukada, N., Sato, T., Mori, H., Sugawara, S., Kabuto, C., Miyano, S. \& Inoue, Y. (2001). J. Organomet. Chem. 627, 121-126.

Turner, M. J., Grabowsky, S., Jayatilaka, D. \& Spackman, M. A. (2014). J. Phys. Chem. Lett. 5, 4249-4255.

Turner, M. J., McKinnon, J. J., Wolff, S. K., Grimwood, D. J., Spackman, P. R., Jayatilaka, D. \& Spackman, M. A. (2017). CrystalExplorer17. The University of Western Australia.

Turner, M. J., Thomas, S. P., Shi, M. W., Jayatilaka, D. \& Spackman, M. A. (2015). Chem. Commun. 51, 3735-3738.

Venkatesan, P., Thamotharan, S., Ilangovan, A., Liang, H. \& Sundius, T. (2016). Spectrochim. Acta Part A, 153, 625-636. 


\section{supporting information}

Acta Cryst. (2019). E75, 1321-1326 [https://doi.org/10.1107/S2056989019011186]

Crystal structure, Hirshfeld surface analysis and interaction energy and DFT studies of 4-[(prop-2-en-1-yloxy)methyl]-3,6-bis(pyridin-2-yl)pyridazine

Mouad Filali, Nada Kheira Sebbar, Tuncer Hökelek, Joel T. Mague, Said Chakroune, Abdessalam Ben-Tama and El Mestafa El Hadrami

Computing details

Data collection: APEX3 (Bruker, 2016); cell refinement: SAINT (Bruker, 2016); data reduction: SAINT (Bruker, 2016); program(s) used to solve structure: SHELXT (Sheldrick, 2015a); program(s) used to refine structure: SHELXL2018 (Sheldrick, 2015b); molecular graphics: DIAMOND (Brandenburg \& Putz, 2012); software used to prepare material for publication: SHELXTL (Sheldrick, 2008).

4-[(Prop-2-en-1-yloxy)methyl]-3,6-bis(pyridin-2-yl)pyridazine

Crystal data

$\mathrm{C}_{18} \mathrm{H}_{16} \mathrm{~N}_{4} \mathrm{O}$

$M_{r}=304.35$

Monoclinic, $P 2_{1} / c$

$a=8.9420(2) \AA$

$b=15.1130(3) \AA$

$c=11.5829(3) \AA$

$\beta=100.132(1)^{\circ}$

$V=1540.91(6) \AA^{3}$

$Z=4$

\section{Data collection}

Bruker D8 VENTURE PHOTON 100 CMOS diffractometer

Radiation source: INCOATEC $\mathrm{I} \mu \mathrm{S}$ micro-focus source

Mirror monochromator

Detector resolution: 10.4167 pixels $\mathrm{mm}^{-1}$

$\omega$ scans

Absorption correction: multi-scan

(SADABS; Krause et al., 2015)

\section{Refinement}

Refinement on $F^{2}$

Least-squares matrix: full

$R\left[F^{2}>2 \sigma\left(F^{2}\right)\right]=0.037$

$w R\left(F^{2}\right)=0.101$

$S=1.04$

3051 reflections

273 parameters

0 restraints
$F(000)=640$

$D_{\mathrm{x}}=1.312 \mathrm{Mg} \mathrm{m}^{-3}$

$\mathrm{Cu} K \alpha$ radiation, $\lambda=1.54178 \AA$

Cell parameters from 9267 reflections

$\theta=4.9-74.5^{\circ}$

$\mu=0.68 \mathrm{~mm}^{-1}$

$T=150 \mathrm{~K}$

Plate, colourless

$0.26 \times 0.24 \times 0.08 \mathrm{~mm}$

$T_{\min }=0.86, T_{\max }=0.95$

11678 measured reflections

3051 independent reflections

2688 reflections with $I>2 \sigma(I)$

$R_{\text {int }}=0.029$

$\theta_{\max }=74.5^{\circ}, \theta_{\min }=4.9^{\circ}$

$h=-10 \rightarrow 10$

$k=-18 \rightarrow 18$

$l=-14 \rightarrow 13$

Primary atom site location: dual space

Secondary atom site location: difference Fourier map

Hydrogen site location: difference Fourier map

All $\mathrm{H}$-atom parameters refined

$w=1 /\left[\sigma^{2}\left(F_{\mathrm{o}}^{2}\right)+(0.0534 P)^{2}+0.3637 P\right]$

where $P=\left(F_{\mathrm{o}}^{2}+2 F_{\mathrm{c}}^{2}\right) / 3$

$(\Delta / \sigma)_{\max }<0.001$ 
$\Delta \rho_{\max }=0.18$ e $\AA^{-3}$

$\Delta \rho_{\min }=-0.15$ e $\AA^{-3}$
Extinction correction: SHELXL2018 (Sheldrick, $2015 b), \mathrm{Fc}^{*}=\mathrm{kFc}\left[1+0.001 \mathrm{xFc}^{2} \lambda^{3} / \sin (2 \theta)\right]^{-1 / 4}$

Extinction coefficient: $0.0046(5)$

\section{Special details}

Geometry. All esds (except the esd in the dihedral angle between two 1.s. planes) are estimated using the full covariance matrix. The cell esds are taken into account individually in the estimation of esds in distances, angles and torsion angles; correlations between esds in cell parameters are only used when they are defined by crystal symmetry. An approximate (isotropic) treatment of cell esds is used for estimating esds involving l.s. planes.

Refinement. Refinement of $\mathrm{F}^{2}$ against ALL reflections. The weighted R-factor $\mathrm{wR}$ and goodness of fit $\mathrm{S}$ are based on $\mathrm{F}^{2}$, conventional R-factors $R$ are based on $F$, with $F$ set to zero for negative $\mathrm{F}^{2}$. The threshold expression of $\mathrm{F}^{2}>2 \operatorname{sigma}\left(\mathrm{F}^{2}\right)$ is used only for calculating R-factors(gt) etc. and is not relevant to the choice of reflections for refinement. R-factors based on $\mathrm{F}^{2}$ are statistically about twice as large as those based on F, and R- factors based on ALL data will be even larger.

Fractional atomic coordinates and isotropic or equivalent isotropic displacement parameters $\left(\AA^{2}\right)$

\begin{tabular}{|c|c|c|c|c|}
\hline & $x$ & $y$ & $z$ & $U_{\text {iso }} * / U_{\text {eq }}$ \\
\hline $\mathrm{O} 1$ & $0.27225(10)$ & $0.47749(5)$ & $0.30640(7)$ & $0.0319(2)$ \\
\hline N1 & $0.19512(11)$ & $0.50876(6)$ & $0.70191(8)$ & $0.0283(2)$ \\
\hline N2 & $0.27872(11)$ & $0.58215(6)$ & $0.70850(8)$ & $0.0283(2)$ \\
\hline N3 & $0.49183(11)$ & $0.71463(6)$ & $0.53716(8)$ & $0.0299(2)$ \\
\hline N4 & $0.07708(13)$ & $0.31558(7)$ & $0.53457(10)$ & $0.0370(3)$ \\
\hline $\mathrm{C} 1$ & $0.17076(12)$ & $0.45900(7)$ & $0.60429(10)$ & $0.0249(2)$ \\
\hline $\mathrm{C} 2$ & $0.23110(12)$ & $0.48225(7)$ & $0.50338(10)$ & $0.0244(2)$ \\
\hline $\mathrm{C} 3$ & $0.31696(12)$ & $0.55846(7)$ & $0.51158(10)$ & $0.0257(2)$ \\
\hline H3 & $0.3616(15)$ & $0.5785(9)$ & $0.4416(12)$ & $0.030(3)^{*}$ \\
\hline $\mathrm{C} 4$ & $0.33924(12)$ & $0.60672(7)$ & $0.61566(9)$ & $0.0244(2)$ \\
\hline $\mathrm{C} 5$ & $0.43278(12)$ & $0.68871(7)$ & $0.63070(10)$ & $0.0250(2)$ \\
\hline C6 & $0.45861(13)$ & $0.73441(8)$ & $0.73683(10)$ & 0.0292 \\
\hline H6 & $0.4125(17)$ & $0.7131(10)$ & $0.8002(13)$ & $0.040(4)^{*}$ \\
\hline $\mathrm{C} 7$ & $0.54897(14)$ & $0.80913(8)$ & $0.74716(11)$ & $0.0329(3)$ \\
\hline $\mathrm{H7}$ & $0.5668(18)$ & $0.8438(11)$ & $0.8229(15)$ & $0.049(4)^{*}$ \\
\hline $\mathrm{C} 8$ & $0.61156(14)$ & $0.83614(8)$ & $0.65191(11)$ & $0.0326(3)$ \\
\hline H8 & $0.6740(17)$ & $0.8887(10)$ & $0.6564(14)$ & $0.042(4)^{*}$ \\
\hline $\mathrm{C} 9$ & $0.57918(14)$ & $0.78700(8)$ & $0.54977(11)$ & 0.0323 \\
\hline H9 & $0.6207(17)$ & $0.8041(10)$ & $0.4814(14)$ & $0.043(4)^{*}$ \\
\hline $\mathrm{C} 10$ & $0.07702(12)$ & $0.37891(7)$ & $0.61505(10)$ & $0.0269(3)$ \\
\hline $\mathrm{C} 11$ & $-0.00417(14)$ & $0.37100(9)$ & $0.70670(11)$ & $0.0346(3)$ \\
\hline H11 & $-0.0048(18)$ & $0.4190(11)$ & $0.7619(14)$ & $0.044(4)^{*}$ \\
\hline $\mathrm{C} 12$ & $-0.08744(15)$ & $0.29497(9)$ & $0.71477(12)$ & 0.0404 \\
\hline H12 & $-0.147(2)$ & $0.2897(11)$ & $0.7774(16)$ & $0.058(5)^{*}$ \\
\hline $\mathrm{C} 13$ & $-0.08794(16)$ & $0.22904(9)$ & $0.63254(12)$ & $0.0405(3)$ \\
\hline $\mathrm{H} 13$ & -0.1415 (19) & $0.1766(12)$ & $0.6368(14)$ & $0.050(4)^{*}$ \\
\hline $\mathrm{C} 14$ & $-0.00414(18)$ & $0.24243(9)$ & $0.54512(13)$ & $0.0440(3)$ \\
\hline $\mathrm{H} 14$ & -0.0035 (19) & $0.1969(11)$ & $0.4852(15)$ & $0.052(5)^{*}$ \\
\hline $\mathrm{C} 15$ & $0.20351(13)$ & $0.43087(8)$ & $0.39007(10)$ & $0.0279(3)$ \\
\hline $\mathrm{H} 15 \mathrm{~A}$ & $0.0898(16)$ & $0.4252(9)$ & $0.3600(12)$ & $0.032(3)^{*}$ \\
\hline H15B & $0.2466(16)$ & $0.3702(10)$ & $0.4016(12)$ & $0.036(4)^{*}$ \\
\hline $\mathrm{C} 16$ & $0.23624(15)$ & $0.43750(8)$ & $0.19364(10)$ & $0.0321(3)$ \\
\hline
\end{tabular}




\begin{tabular}{lllll} 
H16A & $0.1233(17)$ & $0.4420(9)$ & $0.1637(13)$ & $0.037(4)^{*}$ \\
H16B & $0.2670(16)$ & $0.3739(10)$ & $0.1992(13)$ & $0.038(4)^{*}$ \\
C17 & $0.32018(17)$ & $0.48569(9)$ & $0.11329(11)$ & $0.0377(3)$ \\
H17 & $0.436(2)$ & $0.4884(12)$ & $0.1409(17)$ & $0.065(5)^{*}$ \\
C18 & $0.2574(2)$ & $0.51972(11)$ & $0.01194(13)$ & $0.0497(4)$ \\
H18A & $0.150(2)$ & $0.5087(12)$ & $-0.0128(17)$ & $0.065(6)^{*}$ \\
H18B & $0.314(2)$ & $0.5515(13)$ & $-0.0442(18)$ & $0.068(5)^{*}$ \\
\hline
\end{tabular}

Atomic displacement parameters $\left(\AA^{2}\right)$

\begin{tabular}{lllllll}
\hline & $U^{11}$ & $U^{22}$ & $U^{33}$ & $U^{12}$ & $U^{13}$ & $U^{23}$ \\
\hline $\mathrm{O} 1$ & $0.0418(5)$ & $0.0330(4)$ & $0.0225(4)$ & $-0.0060(3)$ & $0.0099(3)$ & $-0.0033(3)$ \\
$\mathrm{N} 1$ & $0.0316(5)$ & $0.0278(5)$ & $0.0259(5)$ & $-0.0019(4)$ & $0.0065(4)$ & $0.0011(4)$ \\
$\mathrm{N} 2$ & $0.0321(5)$ & $0.0283(5)$ & $0.0251(5)$ & $-0.0025(4)$ & $0.0070(4)$ & $0.0001(4)$ \\
$\mathrm{N} 3$ & $0.0351(5)$ & $0.0306(5)$ & $0.0249(5)$ & $-0.0051(4)$ & $0.0079(4)$ & $-0.0004(4)$ \\
$\mathrm{N} 4$ & $0.0503(7)$ & $0.0280(5)$ & $0.0348(6)$ & $-0.0061(4)$ & $0.0129(5)$ & $-0.0010(4)$ \\
$\mathrm{C} 1$ & $0.0243(5)$ & $0.0250(5)$ & $0.0252(6)$ & $0.0039(4)$ & $0.0035(4)$ & $0.0027(4)$ \\
$\mathrm{C} 2$ & $0.0249(5)$ & $0.0246(5)$ & $0.0236(6)$ & $0.0045(4)$ & $0.0034(4)$ & $0.0014(4)$ \\
$\mathrm{C} 3$ & $0.0272(5)$ & $0.0272(5)$ & $0.0230(6)$ & $0.0019(4)$ & $0.0051(4)$ & $0.0013(4)$ \\
$\mathrm{C} 4$ & $0.0244(5)$ & $0.0259(5)$ & $0.0229(5)$ & $0.0027(4)$ & $0.0038(4)$ & $0.0020(4)$ \\
$\mathrm{C} 5$ & $0.0243(5)$ & $0.0270(5)$ & $0.0235(6)$ & $0.0023(4)$ & $0.0034(4)$ & $0.0015(4)$ \\
C6 & $0.0302(6)$ & $0.0339(6)$ & $0.0239(6)$ & $-0.0026(5)$ & $0.0059(4)$ & $-0.0009(4)$ \\
C7 & $0.0361(6)$ & $0.0348(6)$ & $0.0274(6)$ & $-0.0041(5)$ & $0.0044(5)$ & $-0.0053(5)$ \\
C8 & $0.0350(6)$ & $0.0297(6)$ & $0.0325(7)$ & $-0.0060(5)$ & $0.0047(5)$ & $-0.0006(5)$ \\
C9 & $0.0381(6)$ & $0.0325(6)$ & $0.0277(6)$ & $-0.0065(5)$ & $0.0089(5)$ & $0.0015(5)$ \\
C10 & $0.0264(5)$ & $0.0262(5)$ & $0.0274(6)$ & $0.0024(4)$ & $0.0026(4)$ & $0.0042(4)$ \\
C11 & $0.0336(6)$ & $0.0361(6)$ & $0.0355(7)$ & $-0.0049(5)$ & $0.0101(5)$ & $-0.0016(5)$ \\
C12 & $0.0378(7)$ & $0.0455(7)$ & $0.0399(7)$ & $-0.0096(6)$ & $0.0121(6)$ & $0.0032(6)$ \\
C13 & $0.0434(7)$ & $0.0338(7)$ & $0.0437(8)$ & $-0.0110(6)$ & $0.0059(6)$ & $0.0055(5)$ \\
C14 & $0.0603(9)$ & $0.0310(6)$ & $0.0424(8)$ & $-0.0107(6)$ & $0.0140(6)$ & $-0.0031(6)$ \\
C15 & $0.0320(6)$ & $0.0270(6)$ & $0.0257(6)$ & $-0.0007(4)$ & $0.0079(5)$ & $-0.0004(4)$ \\
C16 & $0.0412(7)$ & $0.0299(6)$ & $0.0254(6)$ & $0.0005(5)$ & $0.0066(5)$ & $-0.0052(4)$ \\
C17 & $0.0486(8)$ & $0.0373(7)$ & $0.0293(7)$ & $0.0008(6)$ & $0.0131(6)$ & $-0.0040(5)$ \\
C18 & $0.0689(11)$ & $0.0476(8)$ & $0.0355(8)$ & $0.0083(7)$ & $0.0170(7)$ & $0.0059(6)$ \\
& & & & & & \\
\hline
\end{tabular}

Geometric parameters $\left(\AA,{ }^{\circ}\right)$

\begin{tabular}{llll}
\hline $\mathrm{O} 1-\mathrm{C} 15$ & $1.4224(13)$ & $\mathrm{C} 8-\mathrm{C} 9$ & $1.3836(17)$ \\
$\mathrm{O} 1-\mathrm{C} 16$ & $1.4237(14)$ & $\mathrm{C} 8-\mathrm{H} 8$ & $0.966(16)$ \\
$\mathrm{N} 1-\mathrm{N} 2$ & $1.3322(13)$ & $\mathrm{C} 9-\mathrm{H} 9$ & $0.968(15)$ \\
$\mathrm{N} 1-\mathrm{C} 1$ & $1.3434(15)$ & $\mathrm{C} 10-\mathrm{C} 11$ & $1.3926(17)$ \\
$\mathrm{N} 2-\mathrm{C} 4$ & $1.3386(14)$ & $\mathrm{C} 11-\mathrm{C} 12$ & $1.3813(18)$ \\
$\mathrm{N} 3-\mathrm{C} 9$ & $1.3370(15)$ & $\mathrm{C} 11-\mathrm{H} 11$ & $0.968(17)$ \\
$\mathrm{N} 3-\mathrm{C} 5$ & $1.3445(14)$ & $\mathrm{C} 12-\mathrm{C} 13$ & $1.378(2)$ \\
$\mathrm{N} 4-\mathrm{C} 10$ & $1.3362(15)$ & $\mathrm{C} 12-\mathrm{H} 12$ & $0.974(17)$ \\
$\mathrm{N} 4-\mathrm{C} 14$ & $1.3400(17)$ & $\mathrm{C} 13-\mathrm{C} 14$ & $1.377(2)$ \\
$\mathrm{C} 1-\mathrm{C} 2$ & $1.4151(15)$ & $\mathrm{C} 13-\mathrm{H} 13$ & $0.931(18)$ \\
$\mathrm{C} 1-\mathrm{C} 10$ & $1.4901(15)$ & $\mathrm{C} 14-\mathrm{H} 14$ & $0.978(17)$
\end{tabular}




\begin{tabular}{|c|c|c|c|}
\hline $\mathrm{C} 2-\mathrm{C} 3$ & $1.3782(15)$ & $\mathrm{C} 15-\mathrm{H} 15 \mathrm{~A}$ & 1.019 (14) \\
\hline $\mathrm{C} 2-\mathrm{C} 15$ & $1.5075(15)$ & $\mathrm{C} 15-\mathrm{H} 15 \mathrm{~B}$ & $0.994(15)$ \\
\hline $\mathrm{C} 3-\mathrm{C} 4$ & $1.3930(15)$ & $\mathrm{C} 16-\mathrm{C} 17$ & $1.4851(18)$ \\
\hline $\mathrm{C} 3-\mathrm{H} 3$ & $1.012(14)$ & C16-H16A & $1.011(15)$ \\
\hline $\mathrm{C} 4-\mathrm{C} 5$ & $1.4880(15)$ & C16-H16B & $0.999(15)$ \\
\hline $\mathrm{C} 5-\mathrm{C} 6$ & $1.3934(16)$ & $\mathrm{C} 17-\mathrm{C} 18$ & $1.314(2)$ \\
\hline $\mathrm{C} 6-\mathrm{C} 7$ & $1.3813(17)$ & $\mathrm{C} 17-\mathrm{H} 17$ & $1.03(2)$ \\
\hline $\mathrm{C} 6-\mathrm{H} 6$ & $0.959(15)$ & $\mathrm{C} 18-\mathrm{H} 18 \mathrm{~A}$ & $0.96(2)$ \\
\hline $\mathrm{C} 7-\mathrm{C} 8$ & $1.3836(17)$ & C18-H18B & $1.01(2)$ \\
\hline $\mathrm{C} 7-\mathrm{H} 7$ & $1.010(17)$ & & \\
\hline $\mathrm{O} 1 \cdots \mathrm{C} 11^{\mathrm{i}}$ & $3.2992(16)$ & $\mathrm{C} 3 \cdots \mathrm{C} 11^{\mathrm{i}}$ & $3.5866(17)$ \\
\hline $\mathrm{O} 1 \cdots \mathrm{H} 3$ & $2.232(14)$ & $\mathrm{C} 6 \cdots \mathrm{C} 12^{\mathrm{iv}}$ & $3.5808(18)$ \\
\hline $\mathrm{O} 1 \cdots \mathrm{H} 11^{\mathrm{i}}$ & $2.850(16)$ & $\mathrm{C} 8 \cdots \mathrm{C} 10^{\mathrm{vi}}$ & $3.5797(17)$ \\
\hline $\mathrm{N} 1 \cdots \mathrm{C} 8^{\mathrm{ii}}$ & $3.4105(15)$ & $\mathrm{C} 11 \cdots \mathrm{C} 15^{\mathrm{i}}$ & $3.5633(18)$ \\
\hline $\mathrm{N} 4 \cdots \mathrm{C} 15$ & $2.7895(16)$ & $\mathrm{C} 1 \cdots \mathrm{H} 7^{\mathrm{ii}}$ & $2.925(17)$ \\
\hline $\mathrm{N} 1 \cdots \mathrm{H} 8^{\mathrm{ii}}$ & $2.586(15)$ & $\mathrm{C} 6 \cdots \mathrm{H} 16 \mathrm{~B}^{\mathrm{v}}$ & $2.933(15)$ \\
\hline $\mathrm{N} 1 \cdots \mathrm{H} 11$ & $2.441(16)$ & $\mathrm{C} 9 \cdots \mathrm{H} 15 \mathrm{~B}^{\mathrm{v}}$ & $2.842(15)$ \\
\hline $\mathrm{N} 1 \cdots \mathrm{H} 15 \mathrm{~A}^{\mathrm{i}}$ & $2.713(14)$ & $\mathrm{C} 18 \cdots \mathrm{H} 8^{\mathrm{vii}}$ & $2.920(16)$ \\
\hline $\mathrm{N} 2 \cdots \mathrm{H} 18 \mathrm{~B}^{\mathrm{iii}}$ & $2.86(2)$ & H6 $\cdots H 9^{\text {viii }}$ & $2.56(2)$ \\
\hline $\mathrm{N} 2 \cdots \mathrm{H} 13^{\text {iv }}$ & $2.744(17)$ & $\mathrm{H} 8 \cdots \mathrm{N} 1^{\mathrm{vi}}$ & $2.586(16)$ \\
\hline $\mathrm{N} 2 \cdots \mathrm{H} 6$ & $2.455(15)$ & $\mathrm{H} 11 \cdots \mathrm{H} 16 \mathrm{~A}^{\mathrm{i}}$ & $2.57(2)$ \\
\hline $\mathrm{N} 3 \cdots \mathrm{H} 3$ & $2.522(14)$ & $\mathrm{H} 12 \cdots \mathrm{C} 6^{\mathrm{ix}}$ & $2.886(18)$ \\
\hline $\mathrm{N} 3 \cdots \mathrm{H} 15 \mathrm{~B}^{\mathrm{v}}$ & $2.652(15)$ & $\mathrm{H} 12 \cdots \mathrm{H} 14^{\mathrm{x}}$ & $2.53(3)$ \\
\hline $\mathrm{N} 4 \cdots \mathrm{H} 15 \mathrm{~A}$ & $2.632(14)$ & $\mathrm{H} 13 \cdots \mathrm{H} 18 \mathrm{~B}^{\mathrm{xi}}$ & $2.55(3)$ \\
\hline $\mathrm{N} 4 \cdots \mathrm{H} 15 \mathrm{~B}$ & $2.485(14)$ & $\mathrm{H} 15 \mathrm{~A} \cdots \mathrm{H} 16 \mathrm{~A}$ & $2.36(2)$ \\
\hline $\mathrm{C} 1 \cdots \mathrm{C} 7^{\mathrm{ii}}$ & $3.5853(17)$ & H15B $\cdots H 16 B$ & $2.38(2)$ \\
\hline $\mathrm{C} 2 \cdots \mathrm{C} 10^{\mathrm{i}}$ & $3.5420(15)$ & H16A $\cdots \mathrm{H} 18 \mathrm{~A}$ & $2.33(2)$ \\
\hline $\mathrm{C} 15-\mathrm{O} 1-\mathrm{C} 16$ & $111.09(9)$ & $\mathrm{N} 4-\mathrm{C} 10-\mathrm{C} 1$ & $117.02(10)$ \\
\hline $\mathrm{N} 2-\mathrm{N} 1-\mathrm{C} 1$ & $121.37(9)$ & $\mathrm{C} 11-\mathrm{C} 10-\mathrm{C} 1$ & $120.65(10)$ \\
\hline $\mathrm{N} 1-\mathrm{N} 2-\mathrm{C} 4$ & $119.14(9)$ & $\mathrm{C} 12-\mathrm{C} 11-\mathrm{C} 10$ & $118.85(12)$ \\
\hline $\mathrm{C} 9-\mathrm{N} 3-\mathrm{C} 5$ & $117.07(10)$ & $\mathrm{C} 12-\mathrm{C} 11-\mathrm{H} 11$ & $120.9(9)$ \\
\hline $\mathrm{C} 10-\mathrm{N} 4-\mathrm{C} 14$ & $117.42(11)$ & $\mathrm{C} 10-\mathrm{C} 11-\mathrm{H} 11$ & $120.3(10)$ \\
\hline $\mathrm{N} 1-\mathrm{C} 1-\mathrm{C} 2$ & $121.82(10)$ & $\mathrm{C} 13-\mathrm{C} 12-\mathrm{C} 11$ & $119.41(12)$ \\
\hline $\mathrm{N} 1-\mathrm{C} 1-\mathrm{C} 10$ & $113.24(10)$ & $\mathrm{C} 13-\mathrm{C} 12-\mathrm{H} 12$ & $121.3(10)$ \\
\hline $\mathrm{C} 2-\mathrm{C} 1-\mathrm{C} 10$ & $124.93(10)$ & $\mathrm{C} 11-\mathrm{C} 12-\mathrm{H} 12$ & $119.3(10)$ \\
\hline $\mathrm{C} 3-\mathrm{C} 2-\mathrm{C} 1$ & $116.06(10)$ & $\mathrm{C} 14-\mathrm{C} 13-\mathrm{C} 12$ & $117.79(12)$ \\
\hline $\mathrm{C} 3-\mathrm{C} 2-\mathrm{C} 15$ & $119.63(10)$ & $\mathrm{C} 14-\mathrm{C} 13-\mathrm{H} 13$ & $121.0(10)$ \\
\hline $\mathrm{C} 1-\mathrm{C} 2-\mathrm{C} 15$ & $124.29(10)$ & $\mathrm{C} 12-\mathrm{C} 13-\mathrm{H} 13$ & $121.2(10)$ \\
\hline $\mathrm{C} 2-\mathrm{C} 3-\mathrm{C} 4$ & $119.36(10)$ & $\mathrm{N} 4-\mathrm{C} 14-\mathrm{C} 13$ & $124.22(13)$ \\
\hline $\mathrm{C} 2-\mathrm{C} 3-\mathrm{H} 3$ & $119.3(8)$ & $\mathrm{N} 4-\mathrm{C} 14-\mathrm{H} 14$ & $116.4(10)$ \\
\hline $\mathrm{C} 4-\mathrm{C} 3-\mathrm{H} 3$ & $121.3(8)$ & $\mathrm{C} 13-\mathrm{C} 14-\mathrm{H} 14$ & $119.4(10)$ \\
\hline $\mathrm{N} 2-\mathrm{C} 4-\mathrm{C} 3$ & $122.25(10)$ & $\mathrm{O} 1-\mathrm{C} 15-\mathrm{C} 2$ & $108.29(9)$ \\
\hline $\mathrm{N} 2-\mathrm{C} 4-\mathrm{C} 5$ & $115.80(10)$ & $\mathrm{O} 1-\mathrm{C} 15-\mathrm{H} 15 \mathrm{~A}$ & $109.5(8)$ \\
\hline $\mathrm{C} 3-\mathrm{C} 4-\mathrm{C} 5$ & $121.95(10)$ & $\mathrm{C} 2-\mathrm{C} 15-\mathrm{H} 15 \mathrm{~A}$ & $110.0(8)$ \\
\hline $\mathrm{N} 3-\mathrm{C} 5-\mathrm{C} 6$ & $122.61(10)$ & $\mathrm{O} 1-\mathrm{C} 15-\mathrm{H} 15 \mathrm{~B}$ & $110.2(8)$ \\
\hline $\mathrm{N} 3-\mathrm{C} 5-\mathrm{C} 4$ & $116.15(10)$ & $\mathrm{C} 2-\mathrm{C} 15-\mathrm{H} 15 \mathrm{~B}$ & $111.0(8)$ \\
\hline
\end{tabular}




\begin{tabular}{|c|c|c|c|}
\hline $\mathrm{C} 6-\mathrm{C} 5-\mathrm{C} 4$ & $121.24(10)$ & $\mathrm{H} 15 \mathrm{~A}-\mathrm{C} 15-\mathrm{H} 15 \mathrm{~B}$ & $107.9(11)$ \\
\hline $\mathrm{C} 7-\mathrm{C} 6-\mathrm{C} 5$ & $119.03(11)$ & $\mathrm{O} 1-\mathrm{C} 16-\mathrm{C} 17$ & $108.01(10)$ \\
\hline $\mathrm{C} 7-\mathrm{C} 6-\mathrm{H} 6$ & $122.1(9)$ & $\mathrm{O} 1-\mathrm{C} 16-\mathrm{H} 16 \mathrm{~A}$ & $109.7(8)$ \\
\hline $\mathrm{C} 5-\mathrm{C} 6-\mathrm{H} 6$ & $118.8(9)$ & $\mathrm{C} 17-\mathrm{C} 16-\mathrm{H} 16 \mathrm{~A}$ & $109.7(8)$ \\
\hline $\mathrm{C} 6-\mathrm{C} 7-\mathrm{C} 8$ & $118.99(11)$ & $\mathrm{O} 1-\mathrm{C} 16-\mathrm{H} 16 \mathrm{~B}$ & $109.5(9)$ \\
\hline $\mathrm{C} 6-\mathrm{C} 7-\mathrm{H} 7$ & $120.0(9)$ & $\mathrm{C} 17-\mathrm{C} 16-\mathrm{H} 16 \mathrm{~B}$ & $110.4(8)$ \\
\hline $\mathrm{C} 8-\mathrm{C} 7-\mathrm{H} 7$ & $121.0(9)$ & $\mathrm{H} 16 \mathrm{~A}-\mathrm{C} 16-\mathrm{H} 16 \mathrm{~B}$ & $109.5(12)$ \\
\hline $\mathrm{C} 9-\mathrm{C} 8-\mathrm{C} 7$ & $118.05(11)$ & $\mathrm{C} 18-\mathrm{C} 17-\mathrm{C} 16$ & $124.63(15)$ \\
\hline $\mathrm{C} 9-\mathrm{C} 8-\mathrm{H} 8$ & $121.2(9)$ & $\mathrm{C} 18-\mathrm{C} 17-\mathrm{H} 17$ & $120.8(11)$ \\
\hline $\mathrm{C} 7-\mathrm{C} 8-\mathrm{H} 8$ & $120.7(9)$ & $\mathrm{C} 16-\mathrm{C} 17-\mathrm{H} 17$ & $114.5(11)$ \\
\hline $\mathrm{N} 3-\mathrm{C} 9-\mathrm{C} 8$ & $124.25(11)$ & $\mathrm{C} 17-\mathrm{C} 18-\mathrm{H} 18 \mathrm{~A}$ & $116.3(12)$ \\
\hline $\mathrm{N} 3-\mathrm{C} 9-\mathrm{H} 9$ & $115.5(9)$ & $\mathrm{C} 17-\mathrm{C} 18-\mathrm{H} 18 \mathrm{~B}$ & $125.0(12)$ \\
\hline $\mathrm{C} 8-\mathrm{C} 9-\mathrm{H} 9$ & $120.3(9)$ & $\mathrm{H} 18 \mathrm{~A}-\mathrm{C} 18-\mathrm{H} 18 \mathrm{~B}$ & $118.4(16)$ \\
\hline $\mathrm{N} 4-\mathrm{C} 10-\mathrm{C} 11$ & $122.32(11)$ & & \\
\hline $\mathrm{C} 1-\mathrm{N} 1-\mathrm{N} 2-\mathrm{C} 4$ & $0.15(16)$ & $\mathrm{C} 5-\mathrm{C} 6-\mathrm{C} 7-\mathrm{C} 8$ & $-0.24(18)$ \\
\hline $\mathrm{N} 2-\mathrm{N} 1-\mathrm{C} 1-\mathrm{C} 2$ & $-0.61(16)$ & $\mathrm{C} 6-\mathrm{C} 7-\mathrm{C} 8-\mathrm{C} 9$ & $0.57(18)$ \\
\hline $\mathrm{N} 2-\mathrm{N} 1-\mathrm{C} 1-\mathrm{C} 10$ & $178.92(9)$ & $\mathrm{C} 5-\mathrm{N} 3-\mathrm{C} 9-\mathrm{C} 8$ & $-0.14(18)$ \\
\hline $\mathrm{N} 1-\mathrm{C} 1-\mathrm{C} 2-\mathrm{C} 3$ & $0.42(15)$ & $\mathrm{C} 7-\mathrm{C} 8-\mathrm{C} 9-\mathrm{N} 3$ & $-0.4(2)$ \\
\hline $\mathrm{C} 10-\mathrm{C} 1-\mathrm{C} 2-\mathrm{C} 3$ & $-179.06(10)$ & $\mathrm{C} 14-\mathrm{N} 4-\mathrm{C} 10-\mathrm{C} 11$ & $-0.41(18)$ \\
\hline $\mathrm{N} 1-\mathrm{C} 1-\mathrm{C} 2-\mathrm{C} 15$ & $-177.88(10)$ & $\mathrm{C} 14-\mathrm{N} 4-\mathrm{C} 10-\mathrm{C} 1$ & $178.51(11)$ \\
\hline $\mathrm{C} 10-\mathrm{C} 1-\mathrm{C} 2-\mathrm{C} 15$ & $2.64(17)$ & $\mathrm{N} 1-\mathrm{C} 1-\mathrm{C} 10-\mathrm{N} 4$ & $-164.56(10)$ \\
\hline $\mathrm{C} 1-\mathrm{C} 2-\mathrm{C} 3-\mathrm{C} 4$ & $0.20(15)$ & $\mathrm{C} 2-\mathrm{C} 1-\mathrm{C} 10-\mathrm{N} 4$ & $14.96(16)$ \\
\hline $\mathrm{C} 15-\mathrm{C} 2-\mathrm{C} 3-\mathrm{C} 4$ & $178.58(10)$ & $\mathrm{N} 1-\mathrm{C} 1-\mathrm{C} 10-\mathrm{C} 11$ & $14.38(15)$ \\
\hline $\mathrm{N} 1-\mathrm{N} 2-\mathrm{C} 4-\mathrm{C} 3$ & $0.49(16)$ & $\mathrm{C} 2-\mathrm{C} 1-\mathrm{C} 10-\mathrm{C} 11$ & $-166.10(11)$ \\
\hline $\mathrm{N} 1-\mathrm{N} 2-\mathrm{C} 4-\mathrm{C} 5$ & $-179.18(9)$ & $\mathrm{N} 4-\mathrm{C} 10-\mathrm{C} 11-\mathrm{C} 12$ & $0.07(19)$ \\
\hline $\mathrm{C} 2-\mathrm{C} 3-\mathrm{C} 4-\mathrm{N} 2$ & $-0.66(16)$ & $\mathrm{C} 1-\mathrm{C} 10-\mathrm{C} 11-\mathrm{C} 12$ & $-178.81(11)$ \\
\hline $\mathrm{C} 2-\mathrm{C} 3-\mathrm{C} 4-\mathrm{C} 5$ & $179.00(10)$ & $\mathrm{C} 10-\mathrm{C} 11-\mathrm{C} 12-\mathrm{C} 13$ & $0.1(2)$ \\
\hline $\mathrm{C} 9-\mathrm{N} 3-\mathrm{C} 5-\mathrm{C} 6$ & $0.51(17)$ & $\mathrm{C} 11-\mathrm{C} 12-\mathrm{C} 13-\mathrm{C} 14$ & $0.0(2)$ \\
\hline $\mathrm{C} 9-\mathrm{N} 3-\mathrm{C} 5-\mathrm{C} 4$ & $-178.47(10)$ & $\mathrm{C} 10-\mathrm{N} 4-\mathrm{C} 14-\mathrm{C} 13$ & $0.6(2)$ \\
\hline $\mathrm{N} 2-\mathrm{C} 4-\mathrm{C} 5-\mathrm{N} 3$ & $-178.91(10)$ & $\mathrm{C} 12-\mathrm{C} 13-\mathrm{C} 14-\mathrm{N} 4$ & $-0.4(2)$ \\
\hline $\mathrm{C} 3-\mathrm{C} 4-\mathrm{C} 5-\mathrm{N} 3$ & $1.41(15)$ & $\mathrm{C} 16-\mathrm{O} 1-\mathrm{C} 15-\mathrm{C} 2$ & $-173.64(9)$ \\
\hline $\mathrm{N} 2-\mathrm{C} 4-\mathrm{C} 5-\mathrm{C} 6$ & $2.09(15)$ & $\mathrm{C} 3-\mathrm{C} 2-\mathrm{C} 15-\mathrm{O} 1$ & $-2.59(14)$ \\
\hline $\mathrm{C} 3-\mathrm{C} 4-\mathrm{C} 5-\mathrm{C} 6$ & $-177.59(10)$ & $\mathrm{C} 1-\mathrm{C} 2-\mathrm{C} 15-\mathrm{O} 1$ & $175.66(9)$ \\
\hline $\mathrm{N} 3-\mathrm{C} 5-\mathrm{C} 6-\mathrm{C} 7$ & $-0.32(18)$ & $\mathrm{C} 15-\mathrm{O} 1-\mathrm{C} 16-\mathrm{C} 17$ & $-176.11(10)$ \\
\hline $\mathrm{C} 4-\mathrm{C} 5-\mathrm{C} 6-\mathrm{C} 7$ & $178.61(10)$ & $\mathrm{O} 1-\mathrm{C} 16-\mathrm{C} 17-\mathrm{C} 18$ & $-126.92(14)$ \\
\hline
\end{tabular}

Symmetry codes: (i) $-x,-y+1,-z+1$; (ii) $-x+1, y-1 / 2,-z+3 / 2$; (iii) $x, y, z+1$; (iv) $-x, y+1 / 2,-z+3 / 2$; (v) $-x+1,-y+1,-z+1$; (vi) $-x+1, y+1 / 2,-z+3 / 2$; (vii) $-x+1, y-1 / 2,-z+1 / 2$; (viii) $x,-y+3 / 2, z+1 / 2$; (ix) $-x, y-1 / 2,-z+3 / 2$; (x) $x,-y+1 / 2, z+1 / 2$; (xi) $-x, y-1 / 2,-z+1 / 2$.

Hydrogen-bond geometry $\left(A,{ }^{o}\right)$

$C g$ is the centroid of pyridine ring $B(\mathrm{~N} 3 / \mathrm{C} 5-\mathrm{C} 9)$.

\begin{tabular}{lllll}
\hline$D-\mathrm{H} \cdots A$ & $D-\mathrm{H}$ & $\mathrm{H} \cdots A$ & $D \cdots A$ & $D-\mathrm{H} \cdots A$ \\
\hline $\mathrm{C} 8-\mathrm{H} 8 \cdots \mathrm{N} 1^{\mathrm{vi}}$ & $0.966(16)$ & $2.585(16)$ & $3.4104(15)$ & $143.4(12)$ \\
$\mathrm{C} 15-\mathrm{H} 15 B \cdots C g^{\mathrm{v}}$ & $0.994(15)$ & $2.990(15)$ & $3.8760(13)$ & $149.0(11)$ \\
\hline
\end{tabular}

Symmetry codes: (v) $-x+1,-y+1,-z+1 ;$ (vi) $-x+1, y+1 / 2,-z+3 / 2$. 